\title{
Aloe vera based cookies as a functional food
}

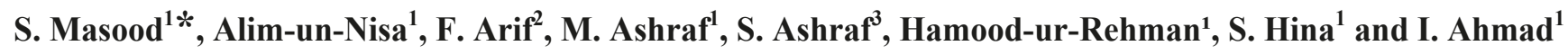 \\ ${ }^{1}$ Food and Biotechnology Research Center, PCSIR, 54600, Lahore, Pakistan \\ ${ }^{2}$ Department of Biological Sciences, Forman Christian College, Lahore, Pakistan \\ ${ }^{3}$ Department of Life Sciences, University of Central Punjab, Lahore, Pakistan
}

Received: 16 October 2021

Revised: 12 October 2021

Accepted: 19 October 2021

DOI: https://doi.org/10.3329/bjsir.v56i4.57201

\begin{abstract}
Cookies are one of the most widely consumed food products that are high in demand worldwide. Based on this fact, an attempt was made to develop the cookies by adding aloe vera gel due to its functional properties. The study was focused on the quality characterization of aloe vera-based cookies in terms of nutritional and sensory attributes. To find out the best formulation, the proximate composition and sensory analysis of biscuits containing $10 \%, 20 \%$ and $30 \%$ aloe vera gel were determined. For overall acceptability, cookies with $20 \%$ aloe vera gel were found best compared to the cookies containing $20 \%$ and $30 \%$ aloe vera gel. Aloe vera-based biscuits may also be helpful for most vulnerable populations in developing countries due to their functional properties.
\end{abstract}

Keywords: Aloe vera; Antioxidants; Mineral contents; Quality attributes; Functional food

\section{Introduction}

A healthy body possesses a healthy mind is a very famous quotation. A healthy diet has a healthy life that can only be achieved by consuming a balanced diet that contains all the essential nutrients required by our body. The importance of essential nutrients and components couldn't be ignored as these are vital for a sound and healthy life. Now a day's food is relatively lower in essential nutrients than the food produced around 50 years ago and to some extended inappropriate agriculture practices have also depleted the quality of soil for agricultural growth. Environmental stress and lifestyle demands have augmented our daily requirement of essential nutrients. To overcome these glitches, research is being done to develop functional food or superfood that promotes health, besides giving basic essential nutrients (Sharma and Dunkwal, 2012).

The term functional food was $1^{\text {st }}$ time used in Japan in 1980 for those food products that contain unique ingredients that are beneficial for the active development of human beings.
Available food may help improve the general conditions of the body or help decrease the specific risk of diseases. The demand for functional food is increasing day by day. Consumers prefer food that provides nutritional and health benefits simultaneously; the dairy industry is far more advanced than the baking industry worldwide in terms of functional food. The baking industry is relatively underdeveloped. However, products of the bakery industry provide an ideal matrix by which functionality can be delivered to the end consumer as an acceptable food (Siro et al., 2008). The baking industry is considered to be a primary food processing industry around the world. Baked products like biscuits and cookies are popular because of their availability and increased shelf life. Most of the biscuits are high in fat, carbohydrates, and less in vitamins and minerals, making them unhealthy to consume. A new recent trend has emerged: incorporating plant extracts, fresh fruit juices and peel powder of various fruits, vegetables and plants in biscuits.

\footnotetext{
*Corresponding author e-mail: shahidmasoodft@gmail.com
} 
The main objective of such a strategy is to improve the overall nutritional quality of biscuits by adding such natural vitamins, minerals, dietary fiber, or antioxidants either through plant or vegetable sources (Paul and Bhattacharyya, 2015).

Aloe vera is known as heavens blessing. Around more than 230 species of aloe Vera are present around the world. Oral ingestion of Aloe vera juice as dietetic good is already being approved by FDA. Aloe vera is also known to be a flavoring composite. Aloe vera is being used in making health-promoting drinks. Aloe vera Powder is being added to bread and biscuits to increase the nutritional stuff of the bread. Aloe vera helped raise the shelf life of various fruits and vegetables by applying a thin coating of aloe Vera gel (Javed, 2014). Two species of Aloe vera Barbadensis and Aloe vera Arborescence have gained more importance due to their medical properties. Aloe vera widely grows in temperate, tropical and subtropical areas. The inner gel of the aloe vera plant has many biological properties and contains nearly 200 bioactive components (Radha and Laxmipriya, 2015). For ages, Aloe vera has been used as a significant source of functional food in juices for promoting human health. Aloe vera is also responsible for microbial inhibition when products are stored for a long time (Javed, 2014). Aloe vera can easily survive in severe drought conditions. Aloe vera is known to be valuable nourishing material and can easily be cultivated in extreme drought conditions. Aloe vera gel contains Vitamin $C$ in excess; meanwhile, it also contains vitamin B1, carotenoids vitamin B2, vitamin B6, niacin, folic acid and the majority of these vitamins also possess a solid antioxidant potential (Rodríguez et al., 2010). Aloe vera also contains minerals; unlike other plants, it has a more significant amount of potassium and chloride. Sodium $(\mathrm{Na})$ is relatively more minor in aloe vera; besides these minerals, it also has magnesium, copper, zinc, chromium, iron, calcium (Javed, 2014).

Using the overall nutritional knowledge to improve the health of the end consumer at the food product level is the general concept of functional food. Biscuits are the most popular and consumed bakery item worldwide. However, it is high in fat, sugar, carbohydrates and less in minerals, vitamins, fibers. Biscuits have a longer shelf life, easy to handle and accepted snacks around the world. Different biscuits varieties are considered as a good food product source for nutritional and fortification improvement (Karklina et al., 2012). To increase biscuits' nutritional value, refined wheat flour was the base material in which aloe vera juice, sugar, butter, sodium bicarbonate, salt was added, later conducted in this study. The overall nutritional improvement of the product was then a primary concern of the study.

\section{Materials and methods}

\section{Raw material purchase}

This research-based study was performed to make a functional food product while determining its nutritional characteristics, antioxidant activity and overall acceptability of the product. The raw material was procured from the local market of Lahore. The research work was done in PCSIR Labs Complex Lahore.

\section{Sample preparation}

The wheat flour was used as a primary ingredient. The aloe vera pulp was incorporated in wheat flour @ 0,10\%, $20 \%$ and $30 \%$ in T0, T1, T2, and T3. Sugar and butter was used at the same concentration of $5 \%$ in each treatment. The table salt and baking soda was also used at the same concentration of $1 \%$. The formulation of dough is given in Table I. The $58 \%$ wheat flour was taken in the dough mixing machine with butter and sugar. The dough of biscuit mix was sheeted and cut into biscuits with the help of a cutter and molds. The biscuits were ready for further processing. The baking of biscuits was done in the baking oven at the lab scale. The baking was done at $170^{\circ} \mathrm{C}$ for about 12 to 15 minutes in a baking oven. After baking, biscuits were packed in air-tied zipper bags for further analysis.

Sample analysis (Moisture, Ash, Crude Protein, Crude Fat, Crude Fiber, Carbohydrates, Vitamin C, Carotenoids, and Minerals)

The moisture content and ash of wheat flour, aloe vera juice and end product aloe vera biscuits were determined according to AACC (2000). The crude protein of wheat flour, aloe vera juice and end product aloe vera biscuits were determined through Kjeldahl method according to AACC (2000). The food samples were digested, neutralized and end step distillation was done. The crude fat of wheat flour, aloe vera juice and end product aloe vera biscuits were determined through Soxhlet apparatus 
Table I. Ingredients and formulation of dough in (\%) concentration

\begin{tabular}{lcccc}
\hline Ingredients & $\begin{array}{c}\text { Biscuits without } \\
\text { any coating } \\
\left(\mathrm{T}_{0}\right)\end{array}$ & $\begin{array}{c}\text { Biscuits with } \\
10 \% \text { aloe vera } \\
\left(\mathrm{T}_{1}\right)\end{array}$ & $\begin{array}{r}\text { Biscuits with } \\
20 \% \text { aloe vera } \\
\left(\mathrm{T}_{2}\right)\end{array}$ & $\begin{array}{r}\text { Biscuits with } \\
30 \% \text { aloe vera } \\
\left(\mathrm{T}_{3}\right)\end{array}$ \\
\hline Wheat flour (g) & 58 & 58 & 58 & 58 \\
Aloe vera (g) & 0 & 10 & 20 & 30 \\
Butter (g) & 5 & 5 & 5 & 5 \\
Sugar (g) & 5 & 5 & 5 & 5 \\
Salt (g) & 1 & 1 & 1 & 1 \\
Baking soda (g) & 1 & 1 & 1 & 1 \\
Water (ml) & 30 & 20 & 10 & 0 \\
\hline
\end{tabular}

Table II. Mean nutritional composition values of aloe vera Biscuits

\begin{tabular}{|c|c|c|c|c|c|c|c|c|}
\hline Samples & $\begin{array}{l}\text { Moisture } \\
(\%)\end{array}$ & $\begin{array}{l}\text { ASH } \\
(\%)\end{array}$ & $\begin{array}{l}\text { Crude } \\
\text { Protein } \\
(\%)\end{array}$ & $\begin{array}{l}\text { Crude } \\
\text { Fiber (\%) }\end{array}$ & $\begin{array}{l}\text { Crude Fat } \\
(\%)\end{array}$ & $\begin{array}{l}\text { Carbohydr } \\
\text { ate }(\%)\end{array}$ & $\begin{array}{l}\text { Vitamin C } \\
(\mathrm{mg} / 100 \mathrm{~g})\end{array}$ & $\begin{array}{l}\text { Beta- } \\
\text { Carotene }\end{array}$ \\
\hline \multirow[t]{2}{*}{$T_{0}$} & 5.233 & 0.176 & 8.443 & 0.230 & 8.510 & 76.707 & 77.767 & 14.330 \\
\hline & $\pm 0.10 \mathrm{~d}$ & $\pm 0.04 \mathrm{~d}$ & $\pm 0.03 \mathrm{~b}$ & $\pm 0.01 \mathrm{~d}$ & $\pm 0.05 \mathrm{a}$ & $\pm 0.20 \mathrm{a}$ & $\pm 0.20 \mathrm{~d}$ & $\pm 0.03 \mathrm{~d}$ \\
\hline \multirow[t]{2}{*}{$T_{1}$} & 6.033 & 0.356 & 9.336 & 0.306 & 8.500 & 74.437 & 80.133 & 41.133 \\
\hline & $\pm 0.01 \mathrm{c}$ & $\pm 0.06 \mathrm{c}$ & $\pm 0.01 \mathrm{a}$ & $\pm 0.06 \mathrm{c}$ & $\pm 0.05 \mathrm{ab}$ & $\pm 0.07 \mathrm{~b}$ & $\pm 0.03 \mathrm{c}$ & $\pm 0.05 \mathrm{c}$ \\
\hline \multirow[t]{2}{*}{$T_{2}$} & 7.166 & 1.466 & 9.360 & 0.373 & 8.446 & 73.220 & 91.900 & 63.067 \\
\hline & $\pm 0.06 \mathrm{~b}$ & $\pm 0.01 \mathrm{~b}$ & $\pm 0.06 \mathrm{a}$ & $\pm 0.05 \mathrm{~b}$ & $\pm 0.02 \mathrm{ab}$ & $\pm 0.16 \mathrm{c}$ & $\pm 0.08 \mathrm{~b}$ & $\pm 0.07 \mathrm{~b}$ \\
\hline \multirow[t]{2}{*}{$T_{3}$} & 8.200 & 1.516 & 9.343 & 0.440 & 8.430 & 72.033 & 121.67 & 80.167 \\
\hline & $\pm 0.10 \mathrm{a}$ & $\pm 0.01 \mathrm{a}$ & $\pm 0.03 \mathrm{a}$ & $\pm 0.01 \mathrm{a}$ & $\pm 0.03 \mathrm{~b}$ & $\pm 0.05 \mathrm{~d}$ & $\pm 0.1 \mathrm{a}$ & $\pm 0.02 \mathrm{a}$ \\
\hline \multicolumn{9}{|c|}{ 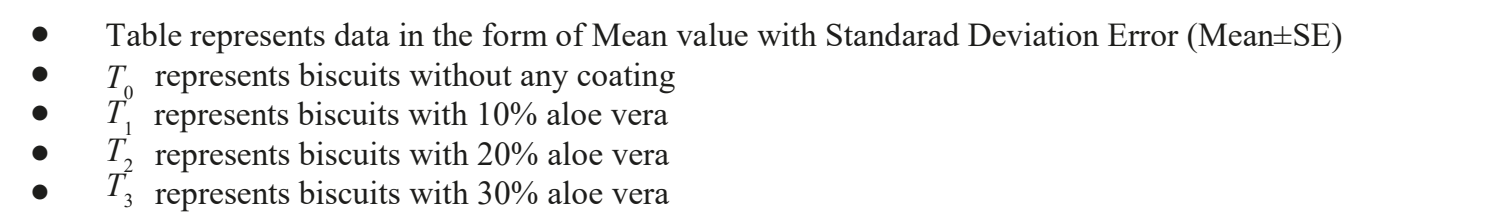 } \\
\hline
\end{tabular}


according to AACC (2000). The crude fiber, carbohydrates, and vitamin $\mathrm{C}$ of wheat flour, aloe vera juice and end product aloe vera biscuits were determined according to the method AACC (2000). The carotenoids content was determined by UV/vis Spectrophotometer (Devi et al., 2018). The use of a flame photometer determines the minerals $(\mathrm{Na}, \mathrm{K}$, and $\mathrm{Ca}$ ) according to (AOAC, 2012).

\section{Results and discussions}

The moisture content (MC) of wheat flour and aloe vera gel was $11.85 \%$ and $98.6 \%$, respectively. The wheat flour moisture was under the standard range. The aloe vera Biscuits moisture content was increased significantly. The variation in moisture content was observed in the control sample and treated ones. The control sample was less in moisture content, and the moisture content of treated biscuits was found higher compared to the control sample. These might be due to the addition of aloe vera, which is rich in water and high water-binding quality.

The ash content (AC) of wheat flour and aloe vera gel was $0.9 \pm 0.02 \% \& 0.19 \pm 0.01 \%$, respectively. The ash content of the aloe vera biscuits was highly significant.
The variation in ash content was observed in the control sample and treated ones. The control sample was less in ash content. At the same time, the ash content of treated biscuits was higher due to aloe vera gel. These might be due to the addition of aloe vera, which is rich in mineral contents that help in increased ash contents.

The protein content (PC) of wheat flour and aloe vera gel was $10.84 \pm 0.2 \%$ and $0.12 \pm 0.01 \%$, respectively. The wheat flour protein was less but ok for biscuit preparation. The protein content of the aloe vera biscuits was significant. The variation in protein content was observed in the control sample and treated ones. The control sample was less in protein content. At the same time, the protein content of treated biscuits was higher in T1, T2 and T3, respectively.

The crude fiber content (CFC) of wheat flour and Aloe Vera gel was $0.8 \pm 0.2 \%$ and $0.16 \pm 0.01 \%$ respectively. The crude fiber content of the Aloe Vera biscuits was significant. The variation in crude fiber content was observed in the control sample and treated ones.

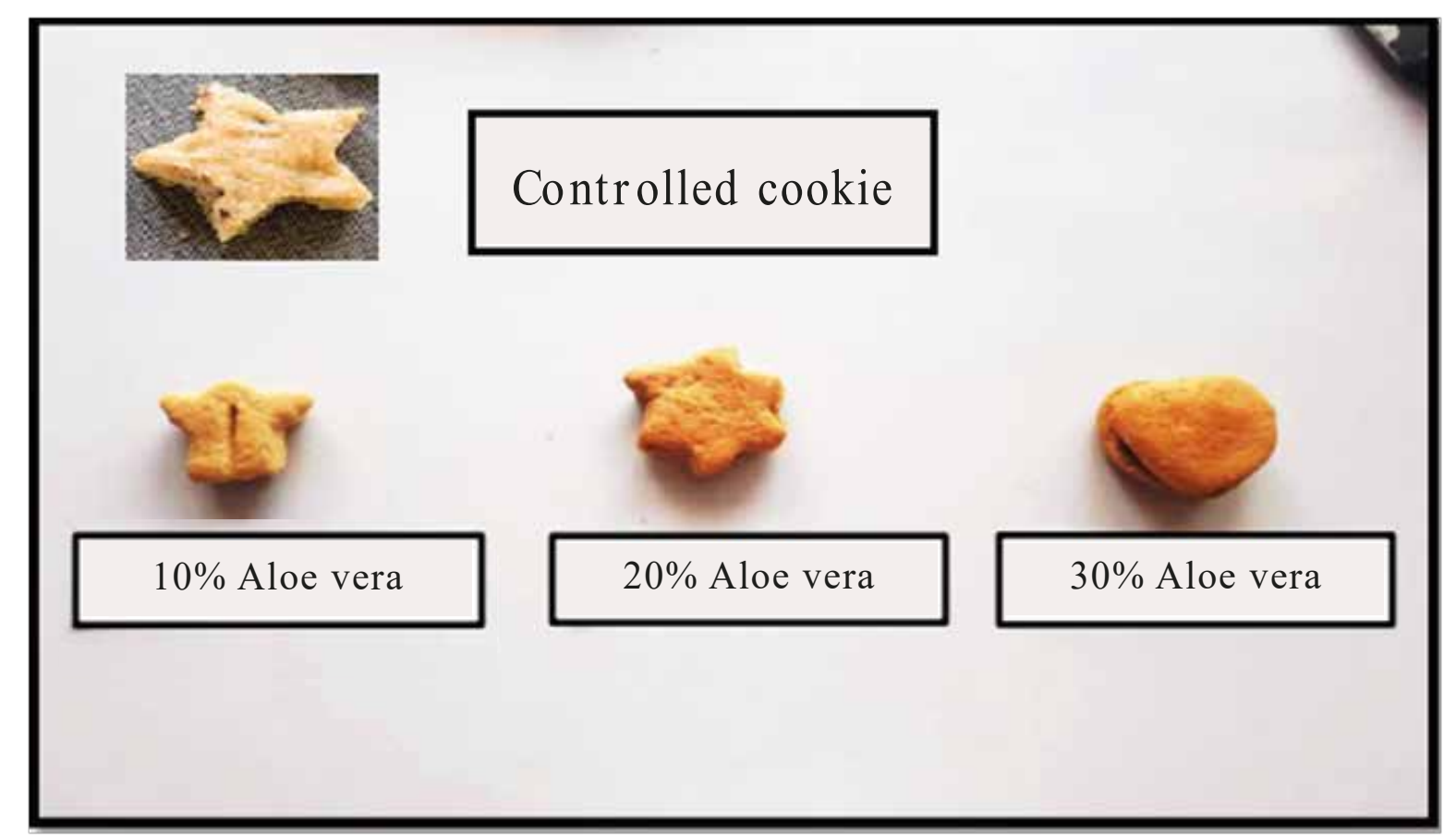

Fig. 1. Aloe vera biscuits contain a) Controlled cookie b) Aloe vera $10 \%$, c) $20 \%$ and d) $30 \%$ respectively 
The control sample was less in crude fiber content. At the same time, the crude fiber content of treated biscuits was higher in T3 than the others.

The crude fat content (CFC) of wheat flour \& aloe vera gel was $1.2 \pm 0.01 \% \& 0.08 \pm 0.01 \%$ respectively. The crude fat content of the aloe vera biscuits was not significant. The variation in crude fat content was observed in the control sample and treated ones. The control sample was higher in fat content, while the crude fat content of treated biscuits was less in treated one than the control sample. The butter was the part of the recipe due to it the crude fat was increased in the controlled sample, while in treated biscuits, aloe vera affected the fat percentage in biscuits.

The carbohydrate content (CC) of wheat flour and aloe vera gel was $0.8 \pm 0.2 \%$ and $0.77 \pm 0.01 \%$, respectively. The carbohydrate content of the aloe vera biscuits was significant. The variation in carbohydrate content was observed in the control sample and treated ones. The control sample was high in carbohydrate content. At the same time, the carbohydrate content of treated biscuits was lower than the control sample.

The Vitamin C (ascorbic acid) content of aloe vera biscuits was analyzed, increasing with the concentration of Aloe Vera gel. The Vitamin $\mathrm{C}$ of the aloe vera biscuits was highly significant. The control sample was lower in Vitamin C, while the antioxidant content of treated biscuits T1, T2, and T3 was $80.133 \mathrm{mg} / 100 \mathrm{~g}, 91.900$ $\mathrm{mg} / 100 \mathrm{~g}$ and $121.67 \mathrm{mg} / 100 \mathrm{~g}$, respectively.

The $\beta$-carotene aloe vera biscuits were analyzed, which was increased with the concentration of aloe vera gel. The $\beta$-carotene of the aloe vera biscuits was highly significant. The control sample was lower in $\beta$-carotene, while the $\beta$-carotene of treated biscuits T1, T2, and T3 was 34 $44.133 \mu \mathrm{g} / \mathrm{g}, 63.067 \mu \mathrm{g} / \mathrm{g}$ and $80.167 \mu \mathrm{g} / \mathrm{g}$, respectively. The overall aloe vera biscuits contents means are enlisted in Table II.

Aloe Vera biscuits with 10\%, 20\%, and 30\% aloe vera juice were prepared, as shown in Figure 1. The panelist liked the overall acceptability of sample T2. The treatment given to biscuits showed significant results at $20 \%$ concentration of aloe vera compared to $10 \% \mathrm{~T} 1$ and $30 \%$ T3. The result showed that biscuits fortified with aloe vera gel provided excellent benefits in improving the overall biscuit nutritional profile plus the quality of baked biscuits.

\section{Conclusion}

Aloe vera gel-based biscuits not only enhance the flavor but also provides health benefits. Therefore, it is suggested that aloe vera gel can be used in the baking industry to provide much more value-added products to the consumer. The addition of aloe vera in the range of $10 \%$ to $20 \%$ results in an excellent baked product. Biscuits prepared with $20 \%$ aloe vera gel got the highest score for texture, color and overall acceptability. It can be proposed to the general public that the embodiment of aloe vera based food items in their daily diet meal plan may be beneficial in controlling health-related diseases.

\section{Acknowledgment}

Authors acknowledge the Pakistan Council of Scientific and Industrial Research for for supporting this research work.

\section{References}

AACC I (2000), Approved Methods of the AACC, Association of Cereal Chemists, St. Paul.

AOAC (2012), Official Methods of Analysis (19 ${ }^{\text {th }}$ Ed.). Association of Official Analytical Chemists, Washington DC, USA.

Devi LS, Devi HN, Karam N and Devi TS (2018), Development of functional biscuit with wheat flour, soy flour and banana rhizome starch, Journal of Pharmacognosy and Phytochemistry 7: 998-1001.

Javed S (2014), Aloe Vera gel in food, health products, and cosmetics industry. In Studies in Natural Products Chemistry 41: 261-285.

Karklina D, Gedrovica I, Reca M and Kronberga M (2012), Production of biscuits with higher nutritional value. In Proceedings of the latvian academy of sciences 66: 113-118. De Gruyter Poland.

Paul P and Bhattacharyya S (2015), Antioxidant profile and sensory evaluation of cookies fortified with 
juice and peel powder of fresh Pomegranate (Punica granatum), International Journal of Agricultural and Food Science 5: 85-91.

Radha MH and Laxmipriya NP (2015), Evaluation of biological properties and clinical effectiveness of Aloe vera: A systematic review, Journal of traditional and complementary medicine 5: 21-26.

Rodríguez ER, Martín JD and Romero CD (2010), Aloe Vera as a functional ingredient in foods.
Critical Reviews in Food, Science and Nutrition 50: 305-326.

Siro I, Kápolna E, Kápolna B and Lugasi (2008), Functional food. Product development, marketing and consumer acceptance, A review. Appetite. 51: 456-467.

Sharma V and Dunkwal V (2012), Development of Spirulina based biscuits : A potential method of value addition, Studies on Ethno-Medicine. 6: 31-34. DOI: org/10.1080/ 09735070. 2012.11886417 